\title{
Mind the Gap: Exploring Hospitality Teachers' and Student Interns' Perception of Using Virtual Communities for Maintaining Connectedness in Internship
}

\author{
Liwei Hsu (Corresponding Author) \\ Graduate Institute of Hospitality Education, National Kaohsiung University of hospitality and \\ Tourism, Kaohsiung City, Taiwan \\ Tel: 886-7-8060505 E-mail: liweihsu@mail.nkuht.edu.tw
}

Received: October 3, 2016

doi:10.5296/jet.v4i1.10933
Accepted: January 4, 2017 Published: February 28, 2017

URL: http://dx.doi.org/10.5296/jet.v4i1.10933

\begin{abstract}
Considerable attention has been given to the relationship between internship and hospitality education and positive results have been extracted. More and more hospitality programs worldwide emphasize the necessity of internship; nevertheless, intern students always considered the lack of support from academic staff as a major challenges for teachers to overcome and virtual community can be exploited as a venue to provide such assistance. The present study surveyed 230 teachers and 660 intern students of hospitality programs in Taiwan and discovered significant differences existed between hospitality teachers and their intern students in terms of their perception about satisfaction, sense of belonging as well as effectiveness of using virtual communities to maintain the connectedness among the teacher and students. When two major social media are compared when being exploited as the platforms for interactions, again, significant differences were discovered with respect to the participants' satisfaction, sense of belong and effectiveness of using Facebook, Line and two of them. Scheffe's Post-hoc further reported that participants' satisfaction with Line was greater than Facebook and their sense of belonging toward the class and effectiveness were stronger when Facebook and Line were used at the same time. Limitations and recommendations for future research are also included in the end of this manuscript.
\end{abstract}

Keywords: Hospitality Education, Internship, Virtual Community, Social Media

\section{Introduction}

The advent and development of Web 2.0 technology has altered the landscape of education context (Hsu, 2012) which also facilitated teachers' as well as students' adoption of internet as a major tool for teaching and learning (Lin, 2010). Gannon, Rodrigo and Santomà (2016) 
suggested that social network sites or any other virtual environments are able to facilitate students' meaningful learning. According to the survey conducted by Taiwan Network Information Center (TWNIC) in 2013, over 16 million out of the entire 23 million population in Taiwan used Internet on daily basis and it seems sound to state that using internet is part of our routine. Therefore, practitioners of education should also exploit the functionality of Web 2.0 technology.

With the emergence social media such as Facebook, Twitter and Line, people are able to create a channel of their own to share many things online and among all these SNSs, the Facebook and Line are the two most popular ones in Taiwan (Huang, Chou, \& Lin, 2014). As Dwyer, Hiltz, and Passerint (2007) pointed out that the emergence of social media facilitated the development of virtual communities. Virtual communities enable more and more people interact with one another via the Internet and gradually altered the way we meet new friends and maintain relationship with the acquaintances (Sonja, 2009). In Taiwan, almost every class has its own virtual community on the Facebook and students are keen to exchange information via this particular channel which has replaced and exceeded the functionality of traditional class management mechanism (Chen, 2013)

Service industry is labor-intense and those which lack desirable service delivered by employees would be put off business; hence qualified work force are greatly sought after (Memis Kocaman \& Kocaman, 2016; Yap \& Ineson, 2016). Internship has played such an important role in the curriculum design of hospitality program (Alonso \& O'Neill, 2011b; Fidgeon, 2010; Hsu, 2013; Jenkins, 2001; Lam \& Ching, 2007; Maier \& Thomas, 2013; Schoffstall \& Arendt, 2016; Tse, 2010; Yiu \& Law, 2012). Busby even emphasized that 'the internship plus degree equates to the "necessary base" for employment' (2001, p. 35). However, discrepancy has been discovered between student's expectation and satisfaction about the internship (Cho, 2006; Tse, 2010). While in their internship, students receive hands-on training in the industry but they are still students to the schools. Teachers would need to be attentive to their learning progress as well as how they get used to the industry tempo. In the National Kaohsuing University of Hospitality and Tourism, all the undergraduate students are required to fulfill one-year internship in the hospitality industry worldwide. When they are out in the industry, teachers as well as advisors would also need to keep in touch with them regularly to make sure that they are all on the right track. Generally speaking, teachers usually are able to pay only one visit to each individual student since they are all working in various areas. However, while students need momentarily assistance from the teacher, he/she may not be able to provide timely help to respond students' calls. With the powerful accessibility and convenience, information communication technologies (ICTs) may be an alternative channel of communication between students and their teacher. Communicating through social media such as the Facebook and/or Line enables the teachers get the recent updates of their students and they can also provide real time advice or encouragement to students when they are experiencing the "culture shock" between the school and the industry. However, pertinent research on the use of social media in hospitality education is still in paucity (Sobaih, Moustafa, Ghandforoush, \& Khan, 2016). 
In order to address and understand whether virtual community can be used by the teachers to maintain connecting to their students who are conducting internship in the industry and possibly provide in-time assistance from perspectives of teachers and students. If it is affirmative, to what extend the virtual community can be helpful to do it, this research is designed to answer the following research questions:

1. What are hospitality teachers' and students' perception on the effectiveness of using virtual community to reach out each other and their satisfaction about using it to enhance their sense of belonging?

2. How did the type of platforms (social media) affect participants' satisfaction, sense of belonging to the class and effectiveness of such use?

To properly address the abovementioned research questions, the present study reviewed pertinent academic works to serve as the rationale to propose research hypotheses. A detailed information about research methodology including sampling technique and instrumentation is showcased followed by research findings as well as discussion. This present study is wrapped up with a conclusion which summarizes important information elicited by the present study.

\section{Virtual Community for Teacher-Students Interaction and Sense of Belonging}

According to Chaskin and Richman (1992), community is defined as "... a place of reference and belonging...the community includes dimensions of space, place, and sentiment as well as action" (p. 113). A class can also be considered as a sort of community which is mainly composed of the teacher and students which is also considered as an epitome of the whole society for the students whose family backgrounds are diverse and are bonded by official relationship and managed by the teacher (Lin, 2013). It has been argued that interactions between the teachers and students play such an important part in classroom management and learning process (Brok, Bergen, Stahl \& Brekelmans, 2004). Further studies also proposed that teacher-student interactions are able to enhance students' own development in learning (Sun, 2007) because both parties can put into joint effort to set the goal and explore the potential path for the students collectively (Kadar, 2001; Lin \& Chen, 2004).

Since teacher-student interaction plays such an important role in students' learning, it is plausible for teachers to strengthen the bonding with students which is also coined as sense of community and within such a community a supportive network can be cultivated (Hahm, Breiter, Severt, Wang, \& Fjelstul, 2016). In the digital era, with the expedient development of web 2.0 technology, virtual communities may go beyond the limitation of time and space and this attribute may be helpful for teachers to maintain the bonding with student interns of hospitality program. However, the paucity of academic work on this issue calls for further exploration.

\section{Internship for Hospitality Program}

Internship has played such an important role in higher education for its being able to help students increase motivation, enrich their knowledge about the subject matters as well as bridge the knowledge and practice (Petrillose \& Montgomery, 1997; Self, Adler, \& Sydnor, 
2016; Yiu \& Law, 2012). Considerable attention has been given to the relationship between internship and hospitality education and positive results have been extracted (Ayres, 2006; Bullock, Gould, Hejmadi, \& Lock, 2009). Similar argument has also been made by Lam and Ching (2007) whose research was administered in Asian context. One major and distinct advantage that internship can offer to the students is the opportunity of networking with the industry before they actually enter the labor market and therefore their marketability increases accordingly. Around $80 \%$ hospitality educators asserted the value of internship in the curriculum which was also supported by the operators of the industry (Alonso \& O'Neill, 2011a; Petrillose \& Montgomery, 1997; Yiu \& Law, 2012). Prior academic works (Brown, Bosselman, \& Thomas, 2016; Kim, McCleary, \& Kaufman, 2010) further asserted that hospitality students with internship experiences tend to commit themselves in searching future career in the hospitality industry. Yet, some weaknesses need to be improved to make the internship valuable to hospitality students' leaning and one of these is lack of funding to visit students on-site on a regular basis and such claims were supported by Lam and Chin (2007) who further indicated that student interns' psychological distress, depression and frustration should be well taken care of by the school mentors. Furthermore, student interns also expect timely feedback from their supervisors as well as teachers to make any necessary adjustment.

Aggett and Busby (2011) looked at this issue from a different perspective and reported an opposite case which decrease the number of hospitality students conducted internship in the UK. Aside from their personal reasons such as not attempting to work in the hospitality industry or had prior work experience already, one major reason which held back students' embarkation of on the internship was the poor design of the programs as also reported by Kwong and Law (2008); specifically, the lack of support from academic staff. Nevertheless, the support proposed by their study referred to students' not being able to truly understand the value of internship and finding the appropriate placement which fitted their aspiration. Not too much has been addressed on the teachers' support after student interns commenced their internship, nor the possibility of virtual community being exploited as a venue to provide such assistance. It has been suggested that educators should facilitate the communication with all parties (students as well as the employers) (Chang \& Chu, 2009). This present study was therefore designed to explore this issue and aimed to provide insightful information about the functionality of virtual community to main teacher-students bonding.

\section{Methodology}

This present study was designed to explore how effective of using virtual community as a means to keep relationships between teachers and their interns on the basis of viewpoints of two sides. There were two groups of participants invited for the survey; namely, teachers of hospitality programs and interns of such programs who were conducting their internship in the industry while this study was undertaking. Details information about the participants, research instrument as well as the research process is depicted as follows:

\subsection{Participants}

Participants of this present study were selected through the technique of stratified 
randomization and 270 teachers as well as 1000 students were invited. After collecting all the questionnaire, 230 copies of the teachers and 660 copies of the students were valid for the following statistical analyses. Details about the participants are presented in the Table 1 below:

Table 1. Demographic Information of Participants

\begin{tabular}{cccccc}
\hline & \multicolumn{2}{c}{ Teachers } & & \multicolumn{2}{c}{ Students } \\
\cline { 2 - 3 } Gender & & & & \\
Female & 178 & $77.40 \%$ & & 385 & $58.30 \%$ \\
Male & 52 & $22.60 \%$ & & 275 & $41.70 \%$ \\
Types of SNSs & & & & \\
Facebook & 11 & $4.80 \%$ & & 50 & $7.60 \%$ \\
Line & 108 & $47.00 \%$ & & 165 & $25.00 \%$ \\
Both & 111 & $48.20 \%$ & & 445 & $67.40 \%$ \\
Location of & & & & \\
School & & & & \\
Northern & 77 & $32.50 \%$ & & 254 & $38.50 \%$ \\
Central & 74 & $32.20 \%$ & & 178 & $27.00 \%$ \\
Southern & 79 & $34.30 \%$ & & 228 & $34.50 \%$ \\
\hline
\end{tabular}

According to the demographic data, female teachers outnumbered male counterparts significantly $(77.40 \%$ to $22.60 \%$ ) and slightly more female students partook this research project $(58.30 \%$ to $41.70 \%)$. Concerning the types of social network sites used by teachers and students, the data showcased that more participants were tending to use Facebook and Line altogether for virtual socialization. Regarding the location of the schools participants were with, the teachers participants were averagely from three major areas of Taiwan while students from the central Taiwan were marginally less represented than ones form the north and the south.

\subsection{Research Instrument}

We adopted the questionnaire developed by Chen (2011), Huang and Lin (2013) and Hsieh (2013) as the research instrument with some modifications to fit the research context properly. The modified questionnaire was undergone reliability and validity examination to ensure the robustness of the question items. Reliability of the research instrument was checked with Cronbach's $\alpha$ and the validity was examined with factor analysis; specifically, factor loading of each item and eigenvalue of each construct were adopted for this task. Details on reliability as well as validity are reported in the Table 2. 
Table 2. Reliability and Validity of Research Instrument

\begin{tabular}{cccccc}
\hline & \multicolumn{3}{c}{ Teachers } & & \multicolumn{2}{c}{ Students } \\
\cline { 2 - 3 } \cline { 5 - 6 } & Cronbach's $\alpha$ & Eigenvalue & & Cronbach's $\alpha$ & Eigenvalue \\
\hline $\begin{array}{c}\text { Satisfaction } \\
(15 \text { items })\end{array}$ & .91 & 6.84 & & .93 & 7.90 \\
$\begin{array}{c}\text { Sense of } \\
\text { Belonging }\end{array}$ & .87 & 4.42 & & .86 & 4.37 \\
$\begin{array}{c}(9 \text { items }) \\
\text { Effectiveness } \\
(11 \text { items })\end{array}$ & .93 & 5.75 & & .87 & 4.83 \\
\hline
\end{tabular}

Information conveyed in the Table 2 explicitly supported the reliability and validity of this research instrument. Cronbach's $\alpha$ of three constructs were all above .80 which indicated the reliability of the instrument is good (George \& Mallery, 2003). With respect to the validity, factor loading of all items was above .50 which is a good indicator of validity (Ghadi et al., 2012; Hair et al., 2010); furthermore, high eigenvalue of each construct provides better explanation of variances in the variables. Based on the aforementioned information and explanation, it is plausible to state that the research instrument is reliable and valid.

\section{Results and findings}

What are hospitality teachers' and intern students' perception on the effectiveness of using virtual community to reach out each other and their satisfaction about using it to enhance their sense of belonging?

In to address the first research question and the results of statistical analyses are presented in the Table 3.

Table 3. Hospitality Teacher and Intern Students' Perception on the Satisfaction about the Effectiveness of Virtual Communities to Enhance Sense of Belonging

\begin{tabular}{|c|c|c|c|c|c|c|c|}
\hline & \multicolumn{2}{|c|}{ Teachers } & \multicolumn{2}{|l|}{ Students } & \multirow{2}{*}{$t$} & \multirow{2}{*}{$p$} & \multirow{2}{*}{ Cohen's $d$} \\
\hline & $M$ & $S D$ & $M$ & $S D$ & & & \\
\hline Satisfaction & 80.15 & 12.85 & 66.66 & 18.65 & 10.16 & .00 & .84 \\
\hline $\begin{array}{l}\text { Sense of } \\
\text { Belonging }\end{array}$ & 45.31 & 9.25 & 42.60 & 10.28 & 3.53 & .00 & .28 \\
\hline Effectiveness & 50.18 & 8.45 & 54.35 & 11.77 & 4.95 & .00 & -.41 \\
\hline
\end{tabular}

Data of two-sample t-test indicates that significant differences (all the $p$ values were less than .00) existed between hospitality teachers and their intern students in terms of their perception about satisfaction, sense of belonging as well as effectiveness of using virtual communities to maintain the connectedness among the teacher and students. Even though the $p$ values informed such differences, they did not elaborate on their effects; thus, effect sizes 
should be performed (Sullivan \& Feinn, 2012). Reports of effect size of such differences was undertaken with Cohen's $d$ and the results showed that Sense of Belonging had a small effect size $(d=.28)$ implied that such a difference did not cause too much effect while Effectiveness had medium effect size $(d=-.41$, negative $d$ indicates the effect is bigger for the intern students.). Satisfaction had the large effect size $(d=.84)$ which postulated hospitality teachers had much greater satisfaction on using virtual communities to reach out their students.

How did the type of platforms (SNSs) affect hospitality participants' perception on satisfaction, sense of belonging to the class and effectiveness of such use?

In order to elicit the effect that various types of platforms caused in hospitality teachers and intern students' satisfaction, sense of belonging to the class and effectiveness of such a use, one-way ANOVA was adopted to test. If the results were to be significant, the follow-up Scheffe post-hoc was run to examine which specific groups differed. Table 4 below demonstrated the results of statistical analyses.

Table 4. One-way ANOVA of How Various Platforms of Virtual Communities Caused to Participants' Perception on Satisfaction, Sense of Belonging, and Effectiveness

\begin{tabular}{ccclccc}
\hline & $F$ & $P$ & $\begin{array}{c}\text { Type of } \\
\text { SNS }\end{array}$ & $M$ & $S D$ & $\begin{array}{c}\text { Scheffe } \\
\text { Post-hoc }\end{array}$ \\
\hline & & & & & \\
Satisfaction & $3.52 *$ & .030 & Lacebook & 60.54 & 18.17 & Line $>$ \\
& & & Both & 68.50 & 17.67 & Facebook \\
Sense of & \multirow{2}{*}{$3.90^{*}$} & .021 & Facebook & 39.72 & 18.95 & \\
Belonging & & & Both & 41.56 & 10.19 & Both $>$ \\
& & & Facebook & 51.12 & 13.13 & Facebook \\
Effectiveness & $4.15 *$ & .016 & Line & 53.02 & 11.87 & Both $>$ \\
& & & Both & 55.20 & 11.48 & Line \\
\hline
\end{tabular}

$* p<.05$

One-way ANOVA indicated that significant differences were discovered with respect to the participants' satisfaction, sense of belong and effectiveness of using Facebook, Line and two of them $(p<.05)$. Scheffe's Post-hoc further reported that participants' satisfaction with Line was greater than Facebook and their sense of belonging toward the class and effectiveness were stronger when Facebook and Line were used at the same time. 


\section{Discussion, Limitation and Conclusion}

The value and importance of internship in hospitality education are no need to emphasize. Having a well-designed internship program will be a great advantage to attract prospective students to attend (Yiu \& Law, 2012; Busby \& Gibson, 2010). To answer this call, the industry and educators should go hand in hand to ensure that students are able to receive fruitful experience in internship and will be willing to enter the industry upon their graduation (Richardson, 2008). Internship serves such an important role to help hospitality students who aspire to seek a career in this industry equip pertinent competence and knowledge through first hand experiences (Lee, Huh, \& Jones, 2016). Disregard many advantages mentioned above, how to take care of intern students has become a challenging issue to hospitality teachers and emerging social media has been considered as one possible solution (Busby \& Gibson, 2010; Sobaih \& Moustafa, 2016). The unique functionality of social media can connect teachers and students in virtual community (Lan, Gou, \& Xi, 2011). Given the popularity of social medias in Taiwan, the present study was designed to examine how the application of the two most popular social medias in Taiwan, namely Facebook and Line, can be used in maintaining connectedness between hospitality teachers and intern students.

Results of the first research question revealed the fact that hospitality teacher and their intern students did perceive maintaining connectedness through SNSs differently in terms of their satisfaction, sense of belonging to the virtual communities as well as the effectiveness. Large effect size indicated that the teachers had much greater satisfaction of virtual communities than the intern students. One possible explanation can be attributed to the replacement of virtual communities to their physical visit in sites. Furthermore, teachers are able to take care of intern students' problem without the limitation of time and space. This point echoes Sobaih and Moustafas' research (2016) which reported teacher-student virtual interaction enables teachers to provide their support to the students.

For teachers' and students' sense of belonging, the present study found that the result was significant but notwithstanding, the effect is small. Moreover, teachers had greater sense of belonging to the class when interactions on social media are entailed. Such a result is somewhat not line with the prior study of Sobaih et al,. (2016), which have confirmed that students are keen to engage more in class if open platforms of communication such as Facebook is exploited. One potential reason may be that students have more virtual communities than teachers on social media and therefore their sense of belonging may be possibly distracted by numerous and various communities. Another reason is what Halm et al. (2016) have pointed out that an individual's satisfaction and sense of community is significantly and positively correlated; therefore, hospitality teachers have greater satisfaction and thus have stronger sense of community.

The effectiveness of using social media as a means for teacher-student interactions, still, significant difference also existed between teachers and students whilst students had greater tendency to consider such application was effective. As Sobaih et al,. (2016) have identified, three major barriers have hindered teachers effectively adopt social media for learning-purpose interactions, which included poor infrastructure, rules and ethical codes of 
as such application, and lack of knowledge of how to use social media as a learning tool. For students of net generation (Oblinger \& Oblinger, 2005), social media has been a part of their daily life and thus they are possibly prone to overcome these barriers effortlessly. However, more empirical evidence is still in need to back up this statement.

The findings of the second research question have put forth an interesting situation, which is that Facebook was the prioritized platform being used for virtual communities in the research of Sobaih et al. (2016), participants of this present study reported that they are more content with Line than Facebook. Hollow (2014) compared the affordances and functionalities of these two platforms and summaries four points which may explain why Line is getting more users in East Asian countries and they are: 1. FB is predominately connected to advertising; 2 . Line provides users with many image-rich "stamps" for them to expressing their feelings and these stamps have become the languages of virtual communities; 3. Some settings of Facebook may possibly baffles privacy; 4. The "high context, low content" cultural characteristics of East Asian countries favors the design of Line. The abovementioned four reasons serve potential explanations why participants of this present research were more satisfied with Line than Faceook.

For participants' sense of belonging as well as their thought on the effectiveness of such adoption, statistical analyses indicate that when participants used both platforms for interactions would achieve stronger sense of belonging and effectiveness. This finding is quite important since Fournier and Ineson (2011) stressed the industry professionals value student interns' professional skills more than technical skills and for students of net generation, professional skills can be cultivated virtually through internet technology (Barnes, Marateo, \& Ferris, 2007). More importantly, in the future, as the higher education goes more multicultural in terms of student population as well as internship placement, adopting technologies to communicate stakeholders synchronously and asynchronously will be more important and realistic than before (Avramenko, 2011). Drawing on results of this study, it is advised that we adopt various genres of social media for interactions since they all have their own advantages and disadvantages.

As Mintzberg and Gosling (2002) have pointed out, competent business managers cannot and should not be trained within the traditional classroom context through lecturing; instead, gaining hands-on experience is essential to business students and hospitality industry is no exception. Such a statement is supported by the study of Ayres (2006). Gannon, Rodrigo, and Santomà (2016) further suggested that "we can extend the functionality and affordance of web 2.0 technologies by creating virtual classrooms which can enhance their virtual, intercultural and team working abilities" (p. 21). Furthermore, the value of internship to hospitality education has already been claimed and in order to make students of hospitality programs being benefitted from internship, teachers should maintain connectedness with their intern students through virtual communities.

The limitations of this study clearly emanate from the fact that the data were retrieved from participants with similar academic and cultural background and it is our hope that we will be able to extend this research scope to include much diversified participants. Moreover, this 
present study used quantitative method to elicit results. Future studies may analyze this issue qualitatively to extend our current understanding to a more in-depth level.

\section{References}

Aggett, M., \& Busby, G. (2011). Opting out of internship: Perceptions of hospitality, tourism and events management undergraduates at a British university. Journal of Hospitality, Leisure, Sport \& Tourism Education, 10(1), 106-113.

Alonso, A. D., \& O’Neill, M. A. (2011b). What defines the "ideal" hospitality employee? A college town case. International Journal of Hospitality \& Tourism Administration, 12, 73-93. doi:10.1080/15256480.2011.540986

Alonso, A. D., \& O'Neill, M. A. (2011a). Can universities assist small hospitality enterprises? The operators' views. Journal of Foodservice Business Research, 14(1), 53-67.

Avramenko, A. (2011). Enhancing students' employability through business simulation. Education + Training, 54(5), 355-367.

Ayres, H. (2006). Education and opportunity as influences on career development: Findings from a preliminary study in Eastern Australian tourism. Journal of Hospitality, Leisure, Sport and Tourism Education, 5(1), 16-27.

Barnes, K., Marateo, R. C., \& Ferris, S. P. (2007). Teaching and learning with the net generation. Innovate: Journal of Online Education, 3(4), 1-8.

Brown, E. A., Bosselman, R. H., \& Thomas, N. J. (2016). Are hospitality graduates making too many compromises? What they give up may lead to turnover. Journal of Human Resources in Hospitality \& Tourism, 15(2), 133-146.

Bullock, K., Gould, V., Hejmadi, M., \& Lock, G. (2009). Work placement experience: Should I stay or should I go? Higher Education Research \& Development, 28(5), 481-494.

Busby, G. (2001). Vocationalism in higher level tourism courses: The British perspective. Journal of Further and Higher Education, 25, 29-43. doi:10.1080/03098770020030489.

Busby, G. D., \& Gibson, P. (2010). Tourism and hospitality internship experiences overseas: A British perspective. Journal of Hospitality, Leisure, Sport and Tourism Education, 9(1), 4-12.

Chang, D., \& Chu, P. (2009). University-industry cooperation in action: A case study of the integrated internship program (IIP) in Taiwan. Journal of Hospitality \& Tourism Education, 21(1), 6-16.

Chaskin, R. J., \& Richman, H. A. (1992). Concerns about school-linked services: institution-based versus community-based models. Future of Children, 2(1), 104-117.

Chen, C. -D. (2011). The Influences of Instructors'Servant Leadership and Teacher-student Interaction on Students' Learning Satisfaction - A Case of T University of Technology. Unpublished Master Thesis, Southern Taiwan University of Science and technology. 
Cho, M. (2006). Student perspectives on the quality of hotel management internships. Journal of Teaching in Travel \& Tourism, 6(1), 61-76.

Fidgeon, P. R. (2010). Tourism education and curriculum design: A time for consolidation and review? Tourism Management, 31, 699-723.

Fournier, H., \& Ineson, E. M. (2011). Closing the gap between education and industry: Skills' and competencies requirements for food service internships in Switzerland. Journal of Hospitality \& Tourism Education, 22(4), 33-42.

Gannon, J., Rodrigo, Z., \& Santomà, R. (2016). Learning to work interculturally and virtually: Developing postgraduate hospitality management students across international $\mathrm{HE}$ institutions. The International Journal of Management Education, 14(1), 18-27.

George, D., \& Mallery, P. (2003). SPSS for Windows step by step: A simple guide and reference. 11.0 update (4th ed.). Boston: Allyn \& Bacon.

Ghadi, I., Alwi, N. H., Bakar, K. A., \& Talib, O. (2012). Construct validity examination of critical thinking dispositions for undergraduate students in university Putra Malaysia. Higher Education Studies, 2(2), 138-145.

Hahm, J. J., Breiter, D., Severt, K., Wang, Y., \& Fjelstul, J. (2016). The relationship between sense of community and satisfaction on future intentions to attend an association's annual meeting. Tourism Management, 52, 151-160.

Hair, J. F., Black, W. C., Balin, B. j., \& Anderson, R. E. (2010). Multivariate data analysis: Maxwell Macmillan International Editions.

Harman, H. H. (1976). Modern factor analysis. Chicago: University Of Chicago Press.

Hollow, J. (2014). Why LINE is eating Facebook's sushi lunch? Retrieved on July $11^{\text {th }}, 2016$ from http://jameshollow.com/blog/line-vs-facebook-in-japan/

Hsieh, C. -t. (2013). A Study of Mathematics Classroom Climate on the Learning Motivation and Satisfaction of Private Vocational High School Students in Taipei City. Unpublished Master Thesis. National Taipei University of Science and Technology, Taiwan.

Huang, Y. -c. \& Lin, S. -h. (2013). The development and study of tutor-student interaction scale for college students. Journal of Advising and Counselling, 35(1), 89-109.

Hung, H. T., \& Yuen, S. C. Y. (2010). Educational use of social networking technology in higher education. Teaching in higher education, 15(6), 703-714.

in Travel \& Tourism, 8(1), 23-45.

Jenkins, A. K. (2001). Making a career of in? Hospitality students' future perspectives: an Anglo-Dutch study. International Journal of Contemporary Hospitality Management, 12(1), $13-20$.

Kim, B., McCleary, K. W., \& Kaufman, T. (2010). The new generation in the industry: Hospitality/ tourism students' career preferences, sources of influence and career choice 
factors. Journal of Hospitality \& Tourism Education, 22(3), 5-11. doi:10.1080/10963758.2010.10696979

Kwong, R., \& Law, R. (2008). The perceptions of graduates and students on quality of a two-year hospitality management program and future development: The case of Hong Kong. Journal of Quality Assurance in Hospitality and Tourism, 9(3), 257-274.

Lam, T., \& Ching, L. (2007). An exploratory study of an internship program: The case of Hong Kong students. International Journal of Hospitality Management, 26(2), 336-351.

Lan, L., Gou, X., \& Xi, J. (2011). SNS communication model applying in network education system. In Computer Science for Environmental Engineering and EcoInformatics (pp. 195-200). Springer Berlin Heidelberg.

Lee, M. J., Huh, C., \& Jones, M. F. (2016). Investigating Quality Dimensions of Hospitality Higher Education: From Students' Perspective. Journal of Hospitality \& Tourism Education, 28(2), 95-106.

Maier, T., \& Thomas, N. (2013). Hospitality leadership course design and delivery: a blended-experiential learning model. Journal of Hospitality \& Tourism Education, 25, 11-21.

Memis Kocaman, E., \& Kocaman, M. (2016). The employment situation of the students studying for food and beverage management bachelor's degree within the sector. International Journal of Social Economics, 43(2), 123-133.

Mintzberg, H., \& Gosling, J. (2002). Educating managers beyond borders. Academy of Management Learning and Education, 1(1), 64-76.

Oblinger, D., \& Oblinger, J. (2005). Is it age or IT: First steps toward understanding the net generation. Educating the Net Generation, 2(1-2), 20. Retrieved from http://judicialaffairs.tamucc.edu/assets/IsItAge.pdf

Petrillose, M. J., \& Montgomery, R. (1997). An exploratory study of internship practices in hospitality education and industry's perception of the importance of internships in hospitality curriculum. Journal of Hospitality \& Tourism Education, 9(4), 46-51.

Richardson, S. (2008). Undergraduate tourism and hospitality students' attitudes

Schoffstall, D. G., \& Arendt, S. W. (2016). Hospitality students' work experiences and an examination of their perceptions of the future. Journal of Human Resources in Hospitality \& Tourism, 15(2), 209-229.

Self, T. T., Adler, H., \& Sydnor, S. (2016). An exploratory study of hospitality internships: Student perceptions of orientation and training and their plans to seek permanent employment with the company. Journal of Human Resources in Hospitality \& Tourism, 15(4), 485-497.

Sobaih, A. E. E., \& Moustafa, M. A. (2016). Speaking the same language: the value of social networking sites for hospitality and tourism higher education in Egypt. Journal of Hospitality \& Tourism Education, 28(1), 21-31. 
Sobaih, A. E. E., Moustafa, M. A., Ghandforoush, P., \& Khan, M. (2016). To use or not to use? Social media in higher education in developing countries. Computers in Human Behavior, 58, 296-305.

Sullivan, G. M., \& Feinn, R. (2012). Using Effect Size - or Why the $P$ Value Is Not Enough. Journal of Graduate Medical Education, 4(3), 279-282. http://doi.org/10.4300/JGME-D-12 $-00156.1$

towards a career in the industry: A preliminary investigation. Journal of Teaching

Tse, T. S. (2010). What do hospitality students find important about internships? Journal of Teaching in Travel \& Tourism, 10(3), 251-264.

Yap, M. H., \& Ineson, E. M. (2016). Diversity management in Vietnam's hospitality industry. Journal of Human Resources in Hospitality \& Tourism, 15(2), 147-165.

Yiu, M., \& Law, R. (2012). A review of hospitality internship: Different perspectives of students, employers, and educators. Journal of Teaching in Travel \& Tourism, 12(4), 377-402.

\section{Copyright Disclaimer}

Copyright reserved by the author(s).

This article is an open-access article distributed under the terms and conditions of the Creative Commons Attribution license (http://creativecommons.org/licenses/by/3.0/). 